\title{
STATISTICAL ANALYSIS AND ESTIMATION OF OIL SATURATION BY TEMPERATURE PARAFFIN
}

\author{
M.K.Karazhanova ${ }^{1}$, O.G.Kirisenko ${ }^{2}$, L.B.Zhetekova ${ }^{1}$, D.B.Smagulova ${ }^{3}$ \\ ${ }^{1}$ Yessenov university, Republic of Kazakhstan \\ ${ }^{2}$ Oil and Gas Institute, NAS of Azerbaijan \\ ${ }^{3}$ Atyrau Oil and Gas University, Republic of Kazakhstan \\ oleg.kirisenko@gmail.com
}

Received 13.04.2021

Accepted 31.05.2021

\begin{abstract}
The article is devoted to the study of the influence of asphalt-resin-paraffin deposits on the temperature of oil saturation by paraffin. As a result of the analysis and generalization of published works and statistical analysis of information, empirical dependences of the temperature of oil saturation by paraffin on the content of asphaltenes, resins and paraffin, were obtained, which were identified for the conditions of the Ural-Volga region and Kazakhstan.
\end{abstract}

Keywords: asphaltene, resin, paraffin, viscosity, oil.

doi

\section{Introduction}

In real geology-physical conditions of displacement of viscous oil, the associated with these anomalies are further enhanced due to the presence of asphaltenes, resins and paraffin's (ARPD) in the composition, the heterogeneity of the collector on various properties, in particular, permeability, and the displacement coefficient decreases with increasing viscosity. The fight against ARPD is complicated due to the lack of knowledge of the mechanism of their formation, their influence on the parameters of oil properties, in particular, the temperature of oil saturation with paraffin, when studying the laws of which, as studies show, there is a lack of consensus. This explains the attention of researchers to the problems associated with the extraction of hard-to-recover oils. This article summarizes and analyzes the methods and methodological approaches for processing the results of studies on the displacement of viscous oils in complex layers.

\section{The state of knowledge of the problem}

Analyzing the concept of "hard-to-recover reserves"(HTRR), it should be noted that according to the majority of researchers, this concept has undergone significant changes over the past decades [1]. Today, oil companies are seriously thinking about development of layers that were previously often not even considered potential reservoirs. There is no single classification of hard-to-recover reserves - too many factors, including economic ones, affect the degree of difficulty in oil or gas production from each particular field. But it is possible to distinguish general criteria: HTRR are reserves enclosed in geologically complex formations and deposits or represented by slow-moving (heavy, high-viscosity) oil. As a rule, they are characterized by relatively low production rates and slow production rates due to low reservoir productivity, unfavorable conditions of oil occurrence or its abnormal physico-chemical properties. The lack of appropriate technologies adapted for the extraction of HTRR and the low profitability of such developments also play a their role. The advanced oil production from highly permeable heterogeneous reservoirs in terms of permeability led to the dismemberment and splitting of the previously single oil-saturated field and the formation of separate sections. Moreover, this phenomenon contributed to the deterioration of the structure of reserves and an increase in the share of hard-to-recover [2-5]. However, the deterioration of the reserve structure was also affected by the fragmentation of collectors, their heterogeneity and intermittency. Judging by the literature sources, two 
groups of works were formed during the research of hard-to-recover oils: works devoted to the research of the properties and conditions of oil occurrence and works devoted to the research of oil compositions. The anomalously viscous properties of oils, especially those containing asphalt-resinous substances, are enhanced during oil cooling not only due to the weakening of the Brownian motion, but also due to the appearance of a new phase-paraffin, as noted in [5] with reference to the work which performed earlier.

At the same time, it should be borne in mind that the temperature of the medium should be lower than the saturation temperature of the oil by paraffin. According to [5], “... the statement of I.M.Amerkhanov [6], the relationship between the paraffin saturation temperature and the mass content of asphalt-resinous substances and paraffin in oil has been revealed. The value of the oil saturation temperature by paraffin is closely related to the mass content of asphaltenes and paraffins and is weakly related to the presence of resins". Moreover, it is noted that with an increase in the mass content of asphaltenes (up to 5-6\%), the paraffin saturation temperature decreases from $32-37$ to 20 $22^{\circ} \mathrm{C}[6,7]$. In [6] was studied the influence of the composition of high-molecular components on the paraffin saturation temperature of oil deposits in the Ural-Volga region. As a result of the observations, which show how close this or that relationship of graphs to the dependence of the oil saturation temperature by paraffin on the content of asphaltenes, resins and high-molecular paraffins.

In $[2,3]$ are considered various methods of developing fields with high-viscosity oil, as well as some methods of developing natural bitumen deposits. It should be noted that the methods of developing bitumen deposits may differ significantly from the methods of developing viscous oil deposits, but in some cases the methods may be applicable to both one and other fields. The choice of the method is mainly influenced by the geologo-physical properties of oil-containing reservoirs and the physical properties of the saturating fluid. Therefore, researchers devote their work to the study of geologo-physical conditions, properties of oils from various fields. Thus, in [8], on the basis of studies of oils from five fields in Kazakhstan and a comparative analysis results of the study of the melting temperatures of paraffins isolated from oil, it was found that this indicator for the Uzen field corresponds to $48^{\circ} \mathrm{C}$, and Botakhan to $44^{\circ} \mathrm{C}$. Paraffins with such a melting point, when heated, naturally pass from the solid state to the liquid. As reported in [8], the melting temperature of paraffin deposits in East Makat, Kumkol and Akshabulak equal 62, 44 and $55^{\circ} \mathrm{C}$ respectively, as shown by the results of thermal analysis of resins to the fields Botakhan and Uzen, where melting point resins equal $62^{\circ} \mathrm{C}$ [8]. Based on the processing of data on the temperature properties of the extracted paraffins from oil, as well as the rheological parameters of oil, the oil saturation temperature with paraffin was calculated, the results are presented in [9]. The analysis of the literature sources indicates various attempts to describe the dependencies for calculating the saturation temperature in layer and surface conditions. This paper provides a brief overview of these dependencies. Thus, according to [8], the authors of [10] propose to use the VNIIneft expression as an equation for calculating the oil saturation temperature by paraffin $[11,12]$ :

$$
t_{\mathrm{o}}=11.398+34.084 \cdot \lg C_{p},
$$

where $t_{\mathrm{o}}$ - is the saturation temperature of oil by paraffin under surface conditions; $C_{p}$ is the concentration of paraffin in oil, mass $\%$.

The literature also provides similar empirical dependences of the saturation temperature on the paraffin content in the form of [13]:

$$
t_{\mathrm{o}}=19.457 \cdot \ln \left(C_{p}\right)-0.8117 \text {. }
$$

In [14-16] it was concluded that the saturation temperature of oil by paraffin depends not only on the paraffin content in it, but also on the presence of resins and asphaltenes, the melting temperature of the extracted paraffin from oil, and the kinematic viscosity at 20 and $50^{\circ} \mathrm{C}$ (the noted dependencies are given in the review, in [9]): 


$$
t_{0}=[\sigma] \cdot\left(\mathrm{K} \cdot \ln \left(T_{\text {resv }}\right)+\mu_{20} / \mu_{50}\right),
$$

where $[\sigma]$ is the correction factor $\left({ }^{0} \mathrm{C} / \%\right) ; \mu_{20}$ is the kinematic viscosity of oil at $20^{\circ} \mathrm{C}\left(\mathrm{mm} / \mathrm{s}^{2}\right)$, $\mu_{50}$ is the kinematic viscosity of oil at $50^{\circ} \mathrm{C}$ $\left(\mathrm{mm} / \mathrm{s}^{2}\right), \mathrm{K}$ is the total content of paraffins, resins and asphaltenes (\%), $T_{\text {melt.p. }}$ is the melting point of paraffin extracted from oil $\left({ }^{0} \mathrm{C}\right)$. In [8], the results of calculations of the oil paraffin saturation temperature are presented using these expressions.

Thus, as the analysis shows that by now a large number has accumulated of the marked dependencies in their various variants and varieties. The data obtained on the oil saturation temperature by paraffin, calculated according to various expressions, differ to some extent due to the underestimation of some factors, but at the same time they allow us to give a qualitative assessment when comparing oils from different fields. Thus, according to [8], the oil of the Uzen field has a higher paraffin saturation temperature. Next are Kumkol and Akshabulak. Regarding the composition of hard-to-recover oils to be that the temperature of the paraffin oil saturation is one of the important indicators, it will provide the opportunity to determine the range of adverse temperatures in the production well production, and make timely decisions to prevent and prevent the formation of paraffin.

The depth of intensive paraffin formation can be estimated, depending on the temperature change along the borehole. The analysis of the results of the performed studies shows that, despite numerous studies, the study of the paraffin saturation temperature of oils is of interest at the present time. However, this requires setting up research on the generalization and statistical processing of the accumulated material, and, if necessary, setting up additional experimental studies.

\section{The results of the research}

To confirm the influence of the content of asphaltenes, resins and paraffin deposits in oil on the oil saturation temperature by paraffin, the accumulated results of experimental studies were generalized and analyzed $[5-7,18]$. The general dependence $t_{\text {paraf }}=f\left(C_{\mathrm{a}}, C_{\mathrm{r}}, C_{\text {paraf }}\right)$ is con- structed, to facilitate the forecast estimation on the basis of the considered partial dependences by their generalization and statistical analysis.

Here $t_{\text {paraf }}$ is the saturation temperature of oil deposits by paraffin; $C_{a}, C_{r}, C_{\text {paraf }}$ is the concentration of asphaltenes, resins, and highmolecular paraffins, respectively, $\%$.

To obtain such dependence, analytical approximations of partial dependencies are first selected, which are subsequently generalized by methods known in mathematical statistics by multiplying them. As a result of the marked transformations, the following expression is obtained:

$t_{\mathrm{sat}}=7.2701 \mathrm{C}_{\mathrm{a}}^{-0.0837}\left(17.41 \cdot \ln \left(C_{p}\right)+1\right)^{0.3787} \mathrm{e}^{0.00855862 C_{\mathrm{r}}}$

Calculations were made for this expression (1) and compared with the experimental data given in $[5,6]$. The results are shown in Table 1.

Table 1. Values of the concentrations of asphaltenes, resins, high-molecular paraffins and the corresponding oil saturation temperatures by paraffins (Ural-Volga region), according to I.M.Amerkhanov

\begin{tabular}{|c|c|c|c|c|c|c|}
\hline$C_{\mathrm{a}}$ & $C_{\mathrm{r}}$ & $C_{\mathrm{p}}$ & $t_{\text {sat calc }}$ & $t_{\text {sat fact aver }}$ & $\Delta t_{\text {sat abs }}$ & $\Delta t_{\text {sat rel }}$ \\
\hline 1.32 & 3.84 & 4.53 & 25.69 & 22.87 & 2.82 & 12.32 \\
\hline 0.53 & 9.76 & 3.28 & 26.74 & 25.45 & 1.29 & 5.06 \\
\hline 2.24 & 12.53 & 4.00 & 25.65 & 28.48 & 2.82 & 9.92 \\
\hline 0.61 & 15.03 & 4.12 & 29.44 & 28.95 & 0.5 & 1.72 \\
\hline 0.55 & 17.39 & 4.22 & 30.49 & 29.49 & 1 & 3.4 \\
\hline 0.41 & 13.73 & 3.13 & 27.2 & 30.9 & 3.08 & 9.7 \\
\hline 0.47 & 20.29 & 4.53 & 32.21 & 32.1 & 0.12 & 0.36 \\
\hline 0.63 & 17.65 & 7.19 & 33.90 & 34.2 & 0.3 & 0.88 \\
\hline
\end{tabular}

A quantitative assessment was determined, which is called a measure of identity, in order to establish the degree of compliance of the obtained expression (1) to real conditions [19]:

$$
Q\left(t_{\text {sat }}\right)=0.697
$$

As can be seen from the comparison of the calculated and experimental data, with a sufficient degree their can be considered close and the dependence, thusit, can be considered acceptable for the research area. It is interesting to study a similar relationship for the conditions of Kazakhstan. For this purpose, an attempt can be made to identify the resulting expression to the conditions of the fields of Kazakhstan or to build the same dependence on the data of 
experimental studies for the oils of the fields of Kazakhstan. It should be noted that, of course, this requires the results of special studies. In the work of Sh.Askarova [8] are summarized the reference to the work performed results for five fields in Kazakhstan. Using this data, we made an attempt to identify the resulting dependence on the conditions of Kazakhstan. As a result of processing the following expression is obtained: $t_{\text {sat }}=0.2996 \exp \left(2.2371 C_{\mathrm{a}}^{-0.047}\left(11.21 \ln \left(C_{p}\right)-\right.\right.$ $\left.1)^{0.2199} \mathrm{e}^{0.004464 C \mathrm{r}}\right)$.

The experimental values of the paraffin saturation temperature for the oils of some fields in Kazakhstan according to [8] in comparison with the calculated values according to expression (2) are shown in Table 2.

The results of comparative calculations showed ambiguity in the accuracy of the model for different fields: if for the Kumkol and Akshabulak fields the relative error is $(3.9-4.6) \%$, then for the other fields it ranges from (20-40) $\%$. This circumstance requires the formulation of special experimental studies.

In [14], it is shown that the temperature of the paraffin oil saturation depends in addition to its content of paraffin along with the contents of resins and asphaltenes, the melting temperature of the selected paraffin oil, and kinematic viscosity at $20^{\circ} \mathrm{C}$ and $50^{\circ} \mathrm{C}$.

Based on the experimental data obtained, the values of the oil saturation temperatures with paraffin are given in [8]. Taking into account the above and the results given in the literature used, the dependence of the oil saturation temperature by paraffin is constructed, both on the content of asphaltenes, resins and paraffin, and the viscosity ratio:

$$
\begin{aligned}
& t_{\text {sat }}=48.228 \cdot C_{\mathrm{a}}^{0.0854}\left(0.8259 C_{\mathrm{r}}-1\right)^{0.4287} C_{p}{ }^{0.2389} \times \\
& \times\left(1.888 \ln \frac{\mu_{20}}{\mu_{50}}-1\right)^{0.4287}
\end{aligned}
$$

Table 3 shows the initial data according to [8], as well as the corresponding calculated values of the oil saturation temperature by paraffin. A measure of identity [19]: $Q\left(t_{\mathrm{sat}}\right)=0.873$.

As can be seen from the table, the calculations for expression (3) give generally quite satisfactory results. For the remaining deposits, the marked expression can be used for approximate calculations. At the same time, the relative error ranges from (6-20) \%, which allows us to use the expression (3). To obtain more accurate forecast data on the values of the oil saturation temperature by paraffin, more detailed, extended experimental studies are necessary. It should be noted that the knowledge of the oil saturation temperature with paraffin is necessary, and this in turn will allow you to control the production during the production process and make the appropriate necessary decisions to prevent and its prevention the formation of ARPD.

Table 2. Values of the paraffin saturation temperature for the oil fields of Kazakhstan in comparison with the calculated data

\begin{tabular}{|c|c|c|c|c|c|}
\hline \multirow{2}{*}{ Oil fields } & \multicolumn{2}{|c|}{ Structural-group composition, $\%$} & \multirow{2}{*}{$\begin{array}{c}\text { The saturation temperature } \\
\text { of the oil with paraffin, }{ }^{0} \mathrm{C}\end{array}$} & $\begin{array}{c}\text { The temperature of the paraffin } \\
\text { oil saturation }\left(\text { calculated), }{ }^{0} \mathrm{C}\right.\end{array}$ \\
\cline { 2 - 5 } & Asphaltenes & Resins & Paraffins & 53.978 \\
\hline Uzen & 2.36 & 16.2 & 21.1 & 22 & 17.534 \\
\hline Botakhan & 0.44 & 4.3 & 3.1 & 16.67 & 24.503 \\
\hline East Makhat & 0.01 & 5.21 & 2.1 & 50 & 52.319 \\
\hline Kumkol & 0.21 & 5.2 & 14.4 & 53 & 55.91 \\
\hline
\end{tabular}

\begin{tabular}{|c|c|c|c|c|c|c|c|c|c|c|}
\hline \multirow{2}{*}{ Oil fields } & \multicolumn{3}{|c|}{ Structural-group composition, $\%$} & \multicolumn{2}{|c|}{$\begin{array}{c}\text { Oil viscosity, } \\
\mathrm{mm} / \mathrm{s}^{2}\end{array}$} & \multirow{2}{*}{$\frac{\mu_{20}}{\mu_{50}}$} & \multirow{2}{*}{$\begin{array}{l}t_{\text {sat factaver }}, \\
{ }^{0} \mathrm{C}\end{array}$} & \multirow{2}{*}{$t_{\text {sat abc }},{ }^{0} \mathrm{C}$} & \multirow{2}{*}{$\Delta \mathrm{t}_{\mathrm{sat} \text { abs }}$} & \multirow{2}{*}{$\Delta \mathrm{t}_{\mathrm{sat} \text { abs }}$} \\
\hline & $\begin{array}{l}\text { Aspha- } \\
\text { ltenes }\end{array}$ & Resins & Paraffins & $\begin{array}{c}\text { at } \\
20^{\circ} \mathrm{C}\end{array}$ & $\begin{array}{c}\text { at } \\
50^{0} \mathrm{C}\end{array}$ & & & & & \\
\hline Botakhan & 0.44 & 4.3 & 3.1 & 12.82 & 6.04 & 2.12 & 22 & 20.6 & 1.4 & 6.39 \\
\hline East Makhat & 0.01 & 5.21 & 2.1 & 11.2 & 4.8 & 2.25 & 16.67 & 19.18 & 2.1 & 15.04 \\
\hline Kumkol & 0.21 & 5.2 & 14.4 & 8.93 & 3.91 & 2.28 & 50 & 40.23 & 9.77 & 19.54 \\
\hline Akshabulak & 0.23 & 6.3 & 16.1 & 13.11 & 4.66 & 2.81 & 53 & 61.15 & 8.15 & 15.7 \\
\hline
\end{tabular}

Table 3. Initial data and corresponding calculated values of the oil saturation temperature with paraffin 


\section{Conclusion}

Currently, the oil industry is experiencing a decline in the quality of raw materials. Among the developed fields, the fields that have already entered the late stage of development predominate. In this regard, there is an increase in the share of hard-to-recover oil reserves, flooding of well production. The oils of most fields are characterized by a high content of ARPD. The presence of ARPD, being a serious problem, causes complications in the operation of wells, oilfield equipment and pipeline communications. A brief review of studies devoted to the study of the properties of paraffin oils showed a great attention of researchers to this problem. Various researchers conducted experimental studies at different times, and built dependencies that allow us to trace the influence of asphaltenes, resins, and paraffins on various properties. Most attention of researchers is attracted by the temperature of oil saturation by paraffins. The analysis and generalization of the results of studies are carried out on the predictive assessment of the oil saturation temperature by paraffin. As a result of statistical processing of experimental data of various researchers, were obtained the dependences of the oil saturation temperature with paraffins on the concentration of asphaltenes, resins and paraffins for some regions. The estimation and comparative analysis of the errors of the obtained models are carried out within the considered fields.

\section{References}

1. Obzor mirovogo opyta dobychi trudnoizvlekaemyh zapasov nefti bitumy Venesuely, neftyanye peski Kanady, slancevaya neft' v SSHA. Rossijskie perspektivy. Sibirskaya neft'. Tekhnologii. Prilozhenie k No3/10 http://www.gazprom-neft.ru > files > journal > SNp100

2. Valihanov, A.V. Razrabotka maloproduktivnyh kollektorov. [Tekst] A.V.Valihanov, E.D.Muharskij, R.H.Muslimov, N.A.Suhanov. Kazan': Tatknigoizdat, 1972. $92 \mathrm{~s}$.

3. Vahitov, G.G., Termodinamika prizabojnoj zony neftyanogo plasta [Tekst] G.G.Vahitov, O.L. Kuznecov, E.M.Simkin .M.: Nedra, 1978. 216 s.

4. Gavura, V.E. Geologiya i razrabotka neftyanyh i gazoneftyanyh mestorozhdenij [Tekst] V.E.Gavura. M.: VNIIOENG. 1995. $496 \mathrm{~s}$.
5. Tupicin A.M. Izvlechenie vyazkoj nefti iz slozhno-postroennyh zalezhej kompleksnymi tekhnologiyami vytesneniya (na primere Bajtuganskogo mestorozhdeniya). Diss. kand. nauk. Bugul'ma. 2017, $145 \mathrm{~s}$.

6. Amerhanov I.M. Zakonomernosti izmeneniya svojstv plastovyh zhidkostej pri razrabotke neftyanyh mestorozhdenij. I.M. Amerhanov. Obzornaya informaciya. Ser. Neftepromyslovoe delo. M.: VNIIOENG, 1980. 49 s.

7. Amerhanov I.M. Plastovye nefti Tatarskoj ASSR i izmeneniya ih parametrov v zavisimosti ot razlichnyh faktorov. Bugul'ma: TatNIPI, 1975. $483 \mathrm{~s}$.

8. Askarova Sh. A. Novye modificirovannye poliolefiny dlya ingibirovaniya asfal'to-smolo-parafinovyh otlozhenij (ASPO) i ochistki technologicheskih neftetruboprovodov. Dissertasiya na soiskanie stepeni doktora filosofii (PhD). Almaty, 2017.

9. Bojko G.I., Lyubchenko N.P., Sarmurzina R.G., Kasymgaliev K.M., Askarova SH.A. Rezul'taty prognozirovaniya obrazovaniya asfal'to-smolo-parafinovyh otlozhenij na skvazhinah mestorozhdenij Zapadnogo Kazahstana Vestnik Kazahstansko-Britanskogo tekhnicheskogo un-ta. 2015. V.12. No 3. S. 26-30.

10. Glushchenko V.N. Silin M.A., Ptashko O.A., Denisova A.B. Neftepromyslovaya himiya: Oslozhneniya v sisteme plast-skvazhina-UPPN: uchebnoe posobie. M.: MAKS Press, 2008. $328 \mathrm{~s}$.

11. Kamenshchikov F.A. Teplovaya deparafinizaciya skvazhin. Izhevsk: NIC "Regulyarnaya i haotichnaya dinamika", 2005. $254 \mathrm{~s}$.

12. Glushchenko V.N. Preduprezhdenie i ustranenie asfal'tenosmoloparafinovyh otlozhenij. Neftepromyslovaya himiya / V.N.Glushchenko, V.N. Silin. M.: Interkontrakt Nauka, 2009. 475 s.

13. Trebin G.F. Nefti mestorozhdenij Sovetskogo Soyuza: Spravochnik. G.F. Trebin, N.V. Charygin, T.M. Obuhova. M.: Nedra, 1980. 583 s.

14. Misnik V.V. Galikeev R.M. Metodika prognozirovaniya glubiny obrazovaniya asfal'tosmoloparafinovyh otlozhenij v skvazhinah Elektronnyj nauchnyj zhurnal "Neftegazovoedelo". 2011. No 6. S. 345-349.

15. Mordvinov V.A. Metodika ocenki glubiny nachala intensivnoj parafinizacii skvazhinnogo oborudovaniya. V.A.Mordvinov, M.S.Turbakov, A.A.Erofeev. Neftyanoe hozyajstvo. 2010. № 7. S. 112-115.

16. Ragulin V.V. Issledovaniya svojstv asfal'tosmoloparafinovyh otlozhenij i razrabotka meropriyatij po ih udaleniyu iz neftepromyslovyh kollektorov. V.V.Ragulin, E.F.Smolyanec, A.G.Mihajlov. Neftepromyslovoe delo. 2001. № 5. S. 33-36.

17. Korobov G.Yu., Rogachev M.K. Issledovanie vliyaniya asfal'to-smolistyh komponentov $\mathrm{v}$ nefti na process obrazovaniya asfal'tosmoloparafinovyh otlozhenij. 162@ Elektronnyj nauchnyj zhurnal 
"Neftegazovoe delo". 2015. No 3. S.162-173. http: www.ogbus.ru

18. Agaeva K.K., Karazhanova M.K., Zhetekova L.B., Smagulova D.B. Analiz metodov izucheniya sostava i svojstv vysokovyazkoj nefti. Oborudovanie i tekhnologii dlya neftegazovogo kompleksa. 2021. № 2(122). S. 69-74.

19. Mirzadzhanzade A.H., Sidorov H.A., Shirinzade S.A. Analiz i proektirovanie pokazatelej bureniya. M.: Nedra, 1976. 237 s.

\section{STATISTIK TəHLIL VӘ NEFTIN PARAFINLO DOYMA TEMPERATURUNUN QIYYMЭTLəNDIRILMӘSI \\ M.K.Karajanova, O.G.Kirisenko, L.B.Jetekova, D.B.Smaqulova}

Məqalə asfalt-qətran-parafin çöküntülərinin neftin parafinlə doyma temperaturuna təsirinin öyrənməsinə həsr edilmişdir. Statistik təhlil nəticəsində asfalten, qətran, parafinlərin neftin parafinlə doyma temperaturuna təsiri öyrənilmiş,Ural-Volqaboyu və Qazaxıstan regionlarına identifikasiya olunmuş müvafiq empirik asılılıqlar qurulmuşdur.

Açar sözlor: asfalten, qatran, parafin, özlülük, neft.

\section{СТАТИСТИЧЕСКИЙ АНАЛИЗ И ОЦЕНКА ТЕМПЕРАТУРЫ НАСЫЩЕНИЯ НЕФТИ ПАРАФИНОМ}

\section{М.К.Каражанова, О.Г. Кирисенко, Л.Б.Жетекова, Д.Б.Смагулова}

Статья посвящена исследованию влияния асфальтосмолистопарафиновых отложений на температуру насыщения нефти парафином. В результате анализа и обобщения опубликованных работ и статистического анализа информации получены эмпирические зависимости температуры насыщения нефти парафином от содержания асфальтенов, смол и парафина, идентифицированные для условий Урало-Поволжья и Казахстана.

Ключевые слова: асфальтен, смола, парафин, вязкость, нефть. 